\title{
A prospective study of fetomaternal outcome in patients of pregnancy with jaundice in tertiary care centre
}

\author{
Monica Arora $^{1}$, Suniti Verma ${ }^{2 *}$, Ranjana Desai ${ }^{1}$, Ram Narain Sehra ${ }^{3}$
}

\begin{abstract}
${ }^{1}$ Department of Obstetrics and Gynaecology, Dr. S. N. Medical College, Jodhpur, Rajasthan, India
${ }^{2}$ Department of Obstetrics and Gynaecology, ${ }^{3}$ Department of Paediatric Medicine, SMS Medical College, Jaipur, Rajasthan, India
\end{abstract}

Received: 20 April 2018

Accepted: 23 May 2018

\section{*Correspondence:}

Dr. Suniti Verma,

E-mail: dr.suniti.verma@gmail.com

Copyright: () the author(s), publisher and licensee Medip Academy. This is an open-access article distributed under the terms of the Creative Commons Attribution Non-Commercial License, which permits unrestricted non-commercial use, distribution, and reproduction in any medium, provided the original work is properly cited.

\begin{abstract}
Background: The objective of the study was to study the incidence of jaundice, biochemical alterations, Fetomaternal outcome and various liver pathologies of pregnant patients with jaundice.

Methods: This was a prospective observational study conducted in Dr S N Medical College Jodhpur, Rajasthan, India from June 2014 to February 2016. Total fifty pregnant patients with clinical jaundice and prodromal symptoms of hepatitis were included in study.

Results: Out of 40,398 deliveries in our hospital, 50 cases of jaundice were identified giving an incidence of 1 in 808 $(0.12 \%)$. Most common cause of jaundice in pregnancy in our set up was viral hepatitis i.e. 13 cases $(26 \%)$ were $\mathrm{HEV}+$ and 1 case $(2 \%)$ came out to be HAV+. Serum LDH levels were raised in $36 \%$ of patients. Maximum no. of patients had their serum AST/ALT levels in the range of 100-1000 IU/ml (54\%). Out of 52 births (2 twins) 34 were live births $(65.38 \%)$ and rest were either SB or IUFDs. Most common causes of mortality in patients were Septicemia, MODS, DIC (25\%) followed by HELLP syndrome and HEV+ viral hepatitis equally (16.67\%). Maximum no. of patients with jaundice suffered from postpartum haemorrage and septicemia $(60 \%)$.

Conclusions: Most common cause of jaundice in pregnancy in our study was viral hepatitis. Public awareness about the various routs of transmission of different types of infective hepatitis, improving sanitary conditions and habits, health education of preventive measures can help in reducing the burden of jaundice in pregnancy.
\end{abstract}

Keywords: Fetomaternal outcome, Jaundice, Mortality, Pregnancy

\section{INTRODUCTION}

Jaundice in pregnancy is a devastating situation which alters the smooth course of pregnancy to the level of moribund state for mother and perinatal mortality as well. Jaundice complicates $3.5 \%$ of pregnancies worldwide and its incidence in India is $0.4-0.9 / 1000$ pregnant women. ${ }^{1,2}$

Viral Hepatitis is the most common form of liver disease worldwide and it frequently affects women of child bearing age. ${ }^{3}$ Jaundice in pregnancy is classified into three categories. First includes diseases coincidental to pregnancy such as acute viral hepatitis. Second category includes diseases unique to pregnancy and caused by it which are hyperemesis gravidarum, cholastasis of pregnancy and preeclampsia. Third category includes pregnancy associated with pre existing liver disease like chronic active hepatitis and wilson's disease. ${ }^{4}$

Physiological alterations in normal pregnancy lead to mild cholestatic state. Clinical features of jaundice like nausea, vomiting, pain abdomen, mild pruritis, palmar erythema, and vascular nevi are seen normally in 
pregnancy. These changes not only alter the course of both acute and chronic liver disease in pregnancy, but may also affect the fetomaternal outcome. ${ }^{5-7}$ Hence the present study was conducted to analyze the etiological factors and fetomaternal outcome of jaundice in pregnancy.

Aims and objective of present study was to evaluate the incidence of jaundice, biochemical alterations, fetomaternal outcome and various liver pathologies of pregnant patients with jaundice.

\section{METHODS}

This was a prospective observational study conducted in Dr S N Medical College Jodhpur, Rajasthan, India from June 2014 to Feb. 2016. Total fifty pregnant patients with jaundice were included in study. Source of data was antenatal patients of this institute. Study was approved by institutional ethical committee.

\section{Inclusion criteria}

All pregnant patients admitted with clinical jaundice and prodromal symptoms of hepatitis like fever with upper quadrant pain, anorexia, malaise, myalgia, arthralgia and vomiting followed by altered liver functions more than two times normal.

\section{Exclusion criteria}

Those delivered outside our tertiary care centre and associated with other co-morbid conditions like congenital heart disease and renal disease

After taking written consent, all patients fulfilling the inclusion criteria were subjected to detailed history, clinical examination and investigations including ANC profile, CBC, urine, blood sugar, liver functions tests, viral markers for hepatitis $\mathrm{A}, \mathrm{B}, \mathrm{C}$ and $\mathrm{E}$, coagulation profile, hepatobiliary abdominal and obstetric ultrasounds were done.

All patients were managed by team collaboration of obstetrician, physician, gastroenterologist, anesthetist and critical care medicine. Soon after delivery all newborns were assessed by pediatrician. Alive or dead, sex, birth weight, gestational age assessment, presence or absence of any congenital malformations were looked for and noted. As per pediatrician opinion sick newborns were admitted in NICU. Maternal outcome was noted in terms of mode of termination of delivery, maternal complications and mortality. Fetal outcome was assessed by perinatal morbidity and mortality.

\section{Statistics}

Results were tabulated in excel sheet and data analyzed as frequencies, percentages and descriptive statistics for the study to be statistically significant.

\section{RESULTS}

Table 1: Clinical presentation.

\begin{tabular}{|lll|}
\hline $\begin{array}{l}\text { Clinical symptoms \& } \\
\text { signs }\end{array}$ & $\begin{array}{l}\text { No. of } \\
\text { patients }\end{array}$ & Percentage \\
\hline Headache & 8 & 16 \\
\hline Convulsions & 5 & 10 \\
\hline Nausea vomiting & 24 & 48 \\
\hline Pruritis & 7 & 14 \\
\hline Loss of appetite & 4 & 8 \\
\hline Pain abdomen & 15 & 30 \\
\hline Respiratory distress & 4 & 8 \\
\hline Icterus & 41 & 82 \\
\hline Hepatospleenomegaly & 9 & 18 \\
\hline Fever & 9 & 18 \\
\hline $\begin{array}{l}\text { Yellow discoloration of } \\
\text { urine }\end{array}$ & 15 & 30 \\
\hline Oedema & 18 & 36 \\
\hline Pallor & 30 & 60 \\
\hline
\end{tabular}

Out of 40,398 deliveries in our hospital, 50 cases of jaundice were identified giving an incidence of 1 in 808 $(0.12 \%)$. Maximum no. of patients i.e. $52 \%$ belonged to age group 12-29 years. Most of the patients were primigravida $(38 \%)$ followed by gravid $2(32 \%)$. The total no. of multigravida was $31(62 \%)$. Maximum no. of patients i.e. $94 \%$ were unbooked. All maternal mortality belongs to unbooked patients (12) and all the IUFDs also contributed by unbooked patients (17). Cases most commonly presented with icterus $(82 \%)$ followed by pallor $(60 \%)$ and nausea and vomiting (48\%) (Table 1). Most common cause of jaundice in pregnancy in our set up was viral hepatitis i.e. 13 cases $(26 \%)$ were $\mathrm{HEV}+$ and 1 case $(2 \%)$ came out to be HAV+. Second most common cause in our setup was septicemia, MODS and DIC (18\%). Most of the cases of HEV+ hepatitis presented in their $3^{\text {rd }}$ trimester (11) although a few (2) cases also presented in $2^{\text {nd }}$ trimester. Similar was the picture with MODS and DIC. Rest of the etiologies were almost always seen in their third trimester.

Serum LDH levels were raised in $36 \%$ of patients. Most of the patients had their billirubin level on admission below $10 \mathrm{mg} \%$ (76\%). Only 2 cases presented with level above $20 \mathrm{mg} \%$ and both suffered from mortality. Maximum no. of patients had their serum AST/ALT levels in the range of $100-1000 \mathrm{IU} / \mathrm{ml}$ (54\%). Only 3 cases (all were $\mathrm{HEV+}$ ) presented with much higher $\mathrm{S}$. AST/ALT levels above $1000 \mathrm{IU} / \mathrm{ml}$. PT and APTT values were abnormal in $10 \%$ and $16 \%$ of patients respectively and all progressed to DIC and mortality (Table 2).

Maximum no. of babies had their birth weigh between $1.5-2.5 \mathrm{~kg}(68 \%)$ but still a few of them were IUFD babies and a few admitted to nursery due to low apgar score. Most of the babies with birth weight above $2.5 \mathrm{~kg}$ had good apgar score and neonatal outcome. Out of 52 births ( 2 twins) 34 were live births $(65.38 \%)$ and rest 
were either SB or IUFDs. Out of all live births, 20 were shifted to NICU and 14 were mother shifted and of all the babies shifted to NICU 4 suffered mortality. Most of the babies had low apgar score at birth and had NICU admission $(38 \%)$. A large no. of infants suffered from intrauterine death probably due to high fetal billirubin and bile acid levels (28\%) (Table 3 ).

Table 2: Laboratory investigations.

\begin{tabular}{|lll|}
\hline Laboratory parameters & No. of patients & $\%$ \\
\hline S. LDH level & & \\
\hline Normal & 32 & 64 \\
\hline Raised & 18 & 36 \\
\hline Bilirubin level & & \\
\hline$<10 \mathrm{mg} \%$ & 38 & 76 \\
\hline $10-14.9 \mathrm{mg} \%$ & 6 & 12 \\
\hline $15-19.9 \mathrm{mg} \%$ & 4 & 8 \\
\hline$>20 \mathrm{mg} \%$ & 2 & 4 \\
\hline S. AST/ALT level & & \\
\hline$<100$ IU/ml & 20 & 40 \\
\hline $100-1000 \mathrm{IU} / \mathrm{ml}$ & 27 & 54 \\
\hline$>1000$ IU/ml & 3 & 6 \\
\hline Coagulation profile & & \\
\hline PT (Normal) & 45 & 90 \\
\hline PT (Abnormal) & 5 & 10 \\
\hline APTT (Normal) & 42 & 84 \\
\hline APTT (Abnormal) & 8 & 16 \\
\hline
\end{tabular}

Most common causes of mortality in patients were Septicemia, MODS, DIC (25\%) followed by HELLP syndrome and $\mathrm{HEV}+$ viral hepatitis equally (16.67\%). Out of the 50 cases observed 12 patients proceeded to mortality making a total of $24 \%$. Grave outcome was seen in patients of septicaemia, MODS and DIC (4SB/IUD, 5 NICU and 5 mortality) and that of HELLP Syndrome (3 SB/IUD, 4 NICU and 2 mortality). Patients included for one or the other reasons (IUFD, eclampsia, preeclampsia, PROM etc) by various methods and all progressed successfully to vaginal delivery except 1 induction by dinoprostone gel (for antepartum eclampsia) which landed into LSCS. Maximum no. of patients delivered preterm babies i.e 44\%, 18 delivered vaginally after 37 completed weeks, 9 by LSCS and 1 atypical case of laprotomy followed by extraction of IUD baby. Most of the maternal mortalities were contributed by disease co- incidental to pregnancy i.e. 10 out of 12 . This group includes viral hepatitis and septicemia (Table 4).

Table 3: Fetal outcome.

\begin{tabular}{|lll|}
\hline $\begin{array}{l}\text { Neonatal variables } \\
\text { Weight of new born }\end{array}$ & No. of patients & $\%$ \\
\hline$<1.5 \mathrm{~kg}$ & 12 & 24 \\
\hline $1.5-2.5 \mathrm{~kg}$ & 31 & 62 \\
\hline$>2.5 \mathrm{~kg}$ & 7 & 14 \\
\hline Gestation & No. of newborns & \\
\hline Preterm & 22 & 44 \\
\hline Term & 18 & 36 \\
\hline Neonatal follow up & No. of newborns & \\
\hline Total live births & 34 (1 twins) & 65.38 \\
\hline SB & 3 & 5.7 \\
\hline IUFD & 15 (1 twins) & 28.8 \\
\hline Early neonatal deaths & 4 & 7.7 \\
\hline
\end{tabular}

Table 4: Etiological distribution according to neonatal outcome and maternal outcome.

\begin{tabular}{|llllll|}
\hline & Total No. of & Neonatal outcome & & \multicolumn{2}{c|}{$\begin{array}{l}\text { Maternal } \\
\text { mortality }\end{array}$} \\
\hline Etiology & Patients $\mathbf{N}(\%)$ & $\begin{array}{l}\text { Live birth } \\
\text { healthy }\end{array}$ & $\begin{array}{l}\text { NICU } \\
\text { admission }\end{array}$ & SB/IUFD & N $(\%)$ \\
\hline HEV +ve & $13(26)$ & 7 & 3 & 3 & $2(15.3)$ \\
\hline HAV +ve & $1(2)$ & 1 & 0 & 0 & 0 \\
\hline HBsAg +ve & $1(2)$ & 0 & 1 & 0 & 0 \\
\hline Septicemia, MODS and DIC & $9(18)$ & 1 & $5(1$ twins $)$ & 4 & $5(55.5)$ \\
\hline Dengue +ve & $2(2)$ & 1 & 1 & 0 & 0 \\
\hline Cerebral Malaria & $1(2)$ & 0 & 0 & 2 twins & $1(100)$ \\
\hline ARDS & $2(4)$ & 0 & 1 & 1 & $2(100)$ \\
\hline Septicemia & $2(4)$ & 0 & 1 & 0 & 0 \\
\hline Cirrhosis & $1(2)$ & 0 & 1 & 0 & 0 \\
\hline Portal HTN & $2(4)$ & 0 & 1 & 0 & 0 \\
\hline Cholestatic & $1(2)$ & 0 & 0 & 0 & 0 \\
\hline $\begin{array}{l}\text { Macrocytic anemia with hemolytic } \\
\text { jaundice }\end{array}$ & $1(2)$ & 1 & 1 & 2 & 0 \\
\hline Antipartum Eclampsia & $3(6)$ & 0 & 4 & 3 & $2(28.5)$ \\
\hline HELLP syndrome & $7(14)$ & 0 & 2 & 2 & 0 \\
\hline $\begin{array}{l}\text { Intrahepatic cholestasis of } \\
\text { pregnancy }\end{array}$ & $4(8)$ & 1 & & & 0 \\
\hline
\end{tabular}


Table 5: Distribution according to complications.

\begin{tabular}{|lll|}
\hline Complications & No. of patients & Percentage \\
\hline Renal dysfunction & 9 & 18 \\
\hline DIC & 12 & 24 \\
\hline PPH & 30 & 60 \\
\hline Septicemia & 30 & 60 \\
\hline ARDS & 2 & 4 \\
\hline Encephalopathy & 6 & 12 \\
\hline $\begin{array}{l}\text { ICU/vasopressor/ } \\
\text { ventilator support }\end{array}$ & 22 & 44 \\
\hline $\begin{array}{l}\text { Antiparturm } \\
\text { hemorrhage }\end{array}$ & 4 & 8 \\
\hline
\end{tabular}

Maximum no. of patients. with jaundice suffered from postpartum haemorrhage and septicemia (60\%) and a larger junk also had ICU stay and associated supports (44\%) showing high morbidity in pregnancy with jaundice (Table 5).

\section{DISCUSSION}

Incidence came out to be comparatively lower in our institution 1 in $808(0.12 \%)$ due to large no. of patients being delivered in our tertiary care which caters whole of western Rajasthan and also the present study excluded those patients who delivered outside the hospital and came in puerperium. Maximum no. of patients reporting with jaundice were in the age group of 21-29 years showing that this is the reproductive age group of population (52\%). Most of the patients were primigravida $(38 \%)$ or either one birth or previous abortion (32\%) giving a total of $70 \%$. Total no. of multigravidas were $62 \%$. Similar incidence was reported by other studies as Nagaria et al $(78 \%$ of women were either primigravidas or $2^{\text {nd }}$ gravid. ${ }^{2}$ Acharya et al concluded that parity has no exact relation with disease, Reddy et al $(61.1 \%$ as primigravida), Nath et al (38\% of primigravidas). ${ }^{8-10}$

The most common symptoms were nausea and vomiting (48\%), pain abdomen $30 \%$ and the incidence of these symptoms was common in all studies as mentioned above. Most common sign was icterus (82\%). Pallor $60 \%$ nearly all patients presented in their $3^{\text {rd }}$ trimester $(86 \%)$. Only 7 out of 50 patients presented in their $2^{\text {nd }}$ trimester. This may be due to etiological susceptibility or delayed diagnosis. All of the 7 were in there $6^{\text {th }}$ month. Similar reports were given by Nagaria et al (95\%), Acharya et al (40 out of 48 pts in their $3^{\text {rd }}$ trimester) and Reddy et al (reported all of the 18 cases in their $3^{\text {rd }}$ trimester).

\section{Etiology}

$30 \%$ of cases were of viral hepatitis. Amongst them, $26 \%$ were infected with hepatitis E virus. Hepatitis E infection is very common in certain geographical areas in India and is one of the most common cause of mortality (16.6\% i.e.
2 out of 16 cases). It was shown that viral hepatitis was common cause of jaundice in pregnancy $(30 \%)[26 \%$ $\mathrm{HEV}+, 2 \% \mathrm{HAV}+, 2 \% \mathrm{HBsAG+}$ followed by Septicemia, MODS and DIC (18\%) and HELLP Syndrome (14\%). HELLP Syndrome was seen in $20 \%$ of cases and all of these cases reported in advanced stage of disease with established complications leading to mortality of 2 of 7 cases. Incidence of cholestasis in pregnancy is comparable to those of other studies (10\%). Nath et al reported infective hepatitis $49 \%$, Cholestasis $15 \%$, HELLP syndrome $20 \%$. Acharya et al reported hepatitis $60 \%$ and HELLP syndrome $10 \%$. Barge et al reported HEV 50\%, HAV and HELLP $8.3 \%$ and cholestasis $20.8 \%$. $^{11}$

\section{Laboratory investigations}

Most of patients were having their bilirubin level below $10 \mathrm{mg} \%(76 \%)$. Only 2 patients had bilirubin above $20 \mathrm{mg} \%$. Similarly most of the patients had AST/ALTT levels between $100-1000 \mathrm{IU} / \mathrm{ml} \%$ (54\%) followed by levels below 100IU/ml. Only 3 cases had levels above $1000 \mathrm{IU} / \mathrm{ml}$. Nath $\mathrm{J}$ et al reported $21 \%$ with bilirubin $10-$ $14 \mathrm{mg} \%$ and $15 \%$ above $15 \mathrm{mg} \%$. Similarly, $70 \%$ of the patients had AST, ALT level 36-999 IU/ml followed equally by levels $<35 \mathrm{IU} / \mathrm{ml}$ and $>1000 \mathrm{IU} / \mathrm{ml}(15 \%)$. Reddy et al reported $44.4 \%$ of patients had bilirubin level $>10 \mathrm{mg} \%$. Of all the patients admitted 10\% had PT level more than twice the control and $16 \%$ of patients had APTT level more than twice the control. Nath et al reported $28 \%$ of patients with PT/APTT level raised and $72 \%$ had this level normal.

\section{Mode of delivery}

Maximum no. of patients delivered vaginally without any active intervention needed. 27 out of 50 progressed spontaneously, 3 induced with mefipristone (for IUFD), 3 with oxytocin (IUFD, S. PIH), 3 with tab. Misoprostol (IUFD, S. PIH) and 4 with dinoprostone gel (IUFD, Out of all delivered vaginally, 18 out of 40 were term (45\%) and 22 were preterm $(55 \%) .18 \%$ of all patients were taken for LSCS for obstetric indications. Nath et al reported spontaneous vaginal delivery $59.7 \%$, LSCS in $25.7 \%$. Acharya et al reported prematurity $48 \%$ and maturity $51 \%$.

\section{Fetal outcome}

Among the newborns, maximum no. had weight between $1.5-2.5 \mathrm{~kg}(62 \%)$ followed by weight below $1.5 \mathrm{~kg}$ (24\%). Nath et al reported 35 out of 97 newborns (36\%) as low birth weight $(<2.5 \mathrm{~kg})$ and 52 of 97 newborns $(53.6 \%)$ as normal birth weight $(>2.5 \mathrm{~kg})$. Perinatal mortality was found to be $42.3 \%$ (18 either born SB/IUDs and 4 early neonatal deaths). 34 babies were live born giving a total of $65.3 \%$. Prematurity and intrapartum asphyxia (due to meconium aspiration as found in almost $100 \%$ of deliveries) were found to be the most common 
for NICU admissions and early neonatal deaths. The perinatal mortality reported by Acharya et al (16.6\%) and Nath $(16.4 \%)$ is lesser may be due to the reason that in the present study $34.5 \%$ cases had absent or non reassuring fetal heart status on admission, though the present institute had a very good neonatal care unit.

\section{Maternal morbidity}

Maximum no. of patients suffered from postpartum hemorrhage and septicemia $(60 \%)$ followed by ICU/ vasopressor/ ventilator support (44\%) as required. Other complications were DIC (24\%), renal dysfunction (18\%), encephalopathy (12\%), APH (8\%) and ARDS (4\%). Incidence of $\mathrm{PPH}$ is comparatively higher in the present because of deranged coagulation profile and thrombocytopenia. Acharya et al reported 22 patients required ICU admission and 37 of 48 required blood transfusion. Reddy et al reported pre-eclampsia (5 of 18) and eclampsia (5 of 18) as a mojor complication.

\section{Mortality}

12 out of 50 patients of pregnancy with jaundice expired giving a mortality rate of $24 \%$. Maximum no. of mortality is caused by Septicemia, MODS and DIC (25\%) followed equally by HEV+ and HELLP Syndrome $(16.67 \%)$. Similar incidence of high mortality was reported by Bera et al $19.9 \%$, Nagaria et al $24.4 \%$, Trivedi et al $29.3 \%$, Sapre et al $4.99 \%$, Barge et al $37.5 \%$, Acharya et al $16.67 \%$, Reddy et al $16.66 \%$ and Nath et al $10 \% .^{12-15}$ It shows Septicemia MODS and DIC being the most dangerous entity with 5 out of 9 cases having mortality and 4 babies were born as SB/IUD and 5 were admitted to nursery. Out of the 15 cases of viral hepatitis, 2 patients suffered mortality (both $\mathrm{HEV}+$ ), 3 babies born as SB/IUD, 4 were admitted to nursery and 8 were mother shifted. Similarly with HELLP Syndrome 2 mortalities occur out of 7, 4 babies born SB/IUD, and 3 shifted to nursery.

\section{CONCLUSION}

Most common cause of jaundice in pregnancy in our study was viral hepatitis. Maternal morbidities were PPH and septicemia. Fetomaternal outcome was poor in patients with septicemia. Public awareness about the various routs of transmission of different types of infective hepatitis, improving sanitary conditions and habits, health education of preventive measures can help in reducing the burden of jaundice in pregnancy. All what is needed is to combat the disease at an earlier stage by timely visit and adequate antenatal check up on the part of patient and earliest diagnosis and proper intervention on the part of obstetrician as multispeciality team approach to halt the disease before complications set in.

Funding: No funding sources Conflict of interest: None declared
Ethical approval: The study was approved by the Institutional Ethics Committee

\section{REFERENCES}

1. Jain RK. Management of jaundice in pregnancy. Medicine update. 2010;20:470-6

2. Nagaria T, Agarwal S. Fetomaternal outcome in jaundice during pregnancy. J Obstet Gynecol India. 2005;55(5):424-7

3. Cunningham G, Leveno KJ, Bloom SL, Hauth JC, Rouse DW, Spong CY. Hepatic, gallbladder and pancreatic disorders. Williams Obstetrics. 23rd ed. McGraw Hill, New York; 2010: 1063

4. Bean WB, Cogswell R, Dexter M. Vascular changes of skin in pregnancy: Vascular spider and palmar erythema. Surg Gynecol Obstet. 1949:88(6):739-52.

5. Kumar A, Beniwal M, Kar P, Sharma JB, Murthy NS. Hepatitis E in pregnancy. Int. J Gynaecol Obstet. 2004;85(3):240-4

6. Elinav E, BenDov IZ, Sharpia Y, Daudi N, Alder R, Showel D et al. Acute hepatitis A infection in pregnancy associated with high rates of gestational complications and preterm labour. Gastroenterology. 2006;130(4):1129-34.

7. Banait VS, Sandur V, Parikh F, Murugesh M, Ranka $\mathrm{P}$, Ramesh VS et al. Outcome of acute liver failure due to acute hepatitis in pregnant women. Indian $\mathbf{J}$ Gastroenterol. 2007;26(1):6-10.

8. Acharya N, Acharya S, Shukla S, Athvale R, Shaveta. Study of jaundice in pregnancy. Global J Med Res Gynecol and Obstet. 2013;13(2):25-9.

9. Reddy MG, Prabhakar GC, Vijaya Sree. Maternal and fetal outcome in jaundice complicating pregnancy. J NTR Univ Health Sci. 2014;3(4):231-3

10. Jayati Nath, Bajpayi G, Sharma R. A clinical study on jaundice in pregnancy with special emphasis on fetomaternal outcome. IOSR J Dent Med Sci. 2015;14(3):116-9.

11. Barge N, Ching ling Yi, Dalal AR. Study of jaundice in pregnancy in a tertiary care institute in India. Bombay Hospital J. 2011;53(2):181-3.

12. Bera SK, Sen Gupta A. A 12 year study of maternal deaths in Eden hospital. J Obstet Gynecol India.2002;42:482-8

13. Trivedi SS, Goyal U, Gupta U. A study of maternal mortality due to viral hepatitis J Obstet Gynecol India. 2003;55:551-3.

14. Sapre S, Joshi V. Changing trends of maternal mortality in North Madhya Pradesh. J Obstet Gynecol. 2009;49:53-56.

Cite this article as: Arora M, Verma S, Desai R, Sehra RN. A prospective study of fetomaternal outcome in patients of pregnancy with jaundice in tertiary care centre. Int J Reprod Contracept Obstet Gynecol 2018;7:2737-41. 